\title{
FLOOD DISASTER MANAGEMENT BASED ON EXTREME TROPICAL RAINFALL IN DECADES OF CLIMATE CHANGE IN INDONESIA
}

\author{
Rahmat Gernowo *1凶(iD), Muhamad Irham Nurwidyanto 2 四 (iD) \\ *1, 2 Department of Physic Faculty of Mathematics and Natural Sciences, Diponegoro University, \\ Semarang, Indonesia
}

DOI: https://doi.org/10.29121/IJOEST.v5.i2.2021.177

Article Type: Research Article

Article Citation: Rahmat Gernowo, and Muhamad Irham Nurwidyanto. (2021). FLOOD DISASTER MANAGEMENT BASED ON EXTREME TROPICAL RAINFALL IN DECADES OF CLIMATE CHANGE IN INDONESIA. International Journal of Engineering Science Technologies, 5(2), 124-130. https://doi.org/10.29121/IJOEST.v5.i2.2021.177

Received Date: 28 March 2021

Accepted Date: 30 April 2021

Keywords: Disaster Management; Flood Hazard; Mononobe ; WRF Model; Rainfall ; Cloud Cover

\section{ABSTRACT}

Indonesia's climate classification is divided into three rainfall patterns. The three patterns are Seasonal Pattern, Equatorial Pattern, and Local Pattern (Anti Seasonal). Flood Disaster Management based on extreme rainfall is very much needed, as the analysis was taken as a case study on January 22, 2019, a flood disaster occurred in South Sulawesi. The flood event indicated that there was heavy rain that flushed the South Sulawesi region for several days, which is classified as monsoonal rainfall. This study aims to analyze the characteristics of heavy rain with atmospheric anomalies during these events by calculating rainfall intensity to determine future flooding patterns and using the WRF model to analyze cloud distribution patterns and rainfall distribution. The method used in this research is Mononobe and Weather Research and Forecasting (WRF) using the Fabric Fritsch cumulus parameterization scheme. The analysis showed that the intensity and duration of rainfall of $2,510,25$, and 50 years were obtained from the Mononobe model, as well as from the atmospheric dynamics data, there was rain for 3 consecutive days caused by cumulonimbus type rain clouds. Based on the WRF model, it can be seen that the CAPE value before the onset of rain is quite significant, thus supporting the growth of rain clouds as an important variable in flood disaster management in the South Sulawesi region in particular and the tropical zone in. general.

Motivation/Background: Indonesia is included in a tropical climate where extreme rainfall is important to analyze. The majority of flood disasters in the tropics occur in decades of extreme atmosphere, this is an important reason in this study.

Method: The Mononobe method can be used to calculate the distribution pattern of rainfall intensity throughout 2, 5, 10, 25 , and 50 years, as a prediction of future rainfall intensity patterns. The WRF model is used to calculate the cloud distribution pattern and the spatial distribution of rainfall.

Results: The results of this study obtained patterns of rainfall intensity and duration of 2, 5, 10, 25, and 50 years from the Mononobe model, as well as from the atmospheric dynamics data, there was rain for 3 consecutive days caused by cumulonimbus rain clouds. The pattern of cloud distribution and rainfall at the time of the incident at the WRF model research location.

Conclusions: Analysis of the distribution pattern of rainfall intensity for the periods of 2, 5, 10, 25, and 50 years, as well as the distribution pattern of clouds and rainfall, is very necessary for disaster identification, especially hydrometeorology. This is very important as a variable in flood disaster management, especially in the tropics. 
Rahmat Gernowo, and Muhamad Irham Nurwidyanto

\section{INTRODUCTION}

The effects of climate change in the tropics, especially Indonesia, are already very pronounced when viewed from the variability of extreme rainfall. Flood disaster management is needed to anticipate and minimize incidents and casualties. Seeing the phenomenon of heavy rains which resulted in flooding that caused a lot of losses, both casualties, material, and other victims, it is necessary to have flood disaster management research by identifying events early on through cloud growth. This analysis of cloud growth has a very important role so that it can reduce the impact afterward [1].

In general, Indonesia can be divided into three main climatic patterns by looking at the rainfall patterns for a year. This is supported by research conducted by [2] regarding the classification of Indonesia's climate into three rainfall patterns. The three patterns include Monsoonal Patterns, Equatorial Patterns, and Local Patterns (Anti Monsoonal).

Seeing the phenomenon of heavy rains which resulted in flooding that caused a lot of losses, both casualties, material, and other victims, it is necessary to have a research activity to identify flood events early on through cloud and rain growth. This analysis of cloud growth has a very important role so that it can reduce the impact afterward. Many ways can be done to carry out this analysis. In [3],[4] flooding phenomena in Jakarta, the results of data processing using the WRF model provide detailed time series explanations of several parameters resulting in several significant conclusions.

In this study, local rainfall patterns will be analyzed with extreme rainfall data that caused flooding on January 22,2019 , when extreme rainfall occurred in Sulawesi, which is an area with monsoonal rainfall patterns.

\section{MATERIALS AND METHODS}

Rainfall is one of the most observed climate elements in Indonesia, this is due to the very high variability both spatially and temporally. The specific (unique) location of Indonesia which is flanked by two large continents (Asia and Australia) and two large oceans (Indian and Pacific), the uneven distribution of land and oceans, and the length of the coastline owned by the Indonesian territory causes heavy rainfall. The amount of rainfall intensity is needed in calculating the flood discharge plan based on a rational method, the duration is the duration of the rain event. Generally, high rain intensity lasts for a short time and covers an area that is not too large [5],[6].

Modified Mononobe is a form of rain distribution pattern that is used to calculate the hourly rain distribution pattern which is a development of the Mononobe method. In [7] states that for design purposes, the rainfall design that has been determined based on the analysis results needs to be converted into a rainfall intensity curve. Curves can be obtained based on rainfall data from automatic rain stations with short periods, for example, minutes or hours.

The application of the WRF model according to [8] is quite broad, including microphysical processes (microphysics), cumulus cloud parameterization, planetary boundary layers, surface layers, longwave radiation, short wave radiation, sub-grid turbulence, land use categories to determine surface richness. In the Eta model, it is stated that cumulus parameterization is not a simple problem and it is very difficult to predict the location and motion of convection, this involves differences in the properties of convection in mountainous areas and oceans [9],[10].

The hydrological analysis is a frequency analysis that uses the probability distribution theory of the probability distribution and what is commonly used is the Log Pearson. Determination of Design Flood is needed to get the Rainfall Intensity value, especially if the method used is rational. Rainfall intensity is the height of rainfall that occurs when water is concentrated. This rainfall intensity analysis can be processed from rainfall data that occurred in the past [7].

The rain intensity needed to predict the planned flood needs to be known about the distribution of rain every hour at certain intervals. If daily rainfall data is available, Mononobe proposes the following equation.

$$
I=\frac{R_{24}}{24}\left[\frac{24}{t}\right]^{\frac{2}{3}}
$$


Where:

$\mathrm{I}=$ average rainfall intensity in T hours ( $\mathrm{mm} /$ hour),

$\mathrm{R}_{24}=$ maximum rainfall in 1 day $(\mathrm{mm})$,

$\mathrm{t} \quad=$ duration of rainfall (hours).

The duration of rain is estimated to be more than 2 hours, so to calculate the intensity of rain per hour from daily rain, the Modified-Mononobe method can be used. the concentration which can be calculated by the following equation:

$$
\mathrm{I}_{\mathrm{T}}^{\mathrm{t}}=\frac{\mathrm{R}_{\mathrm{T}, 24}}{24}\left[\frac{\mathrm{t}_{\mathrm{c}}}{\mathrm{t}}\right]^{\mathrm{m}}
$$

Where:

$\mathrm{I}_{\mathrm{T}}^{\mathrm{t}} \quad$ = rain intensity with $\mathrm{T}$ repeat times for duration $\mathrm{t}$ ( $\mathrm{mm} / \mathrm{hour}$ ),

$\mathrm{R}_{\mathrm{T}, 24}=$ daily rainfall intensity for the $\mathrm{T}$ return period ( $\mathrm{mm} /$ day),

$\mathrm{t}=$ rain duration (hours),

$\mathrm{t}_{\mathrm{c}} \quad=$ concentration time (hours),

$\mathrm{m}=$ mononobe constant.

Application of the WRF model to dynamic rain cloud analysis, where the WRF model has developed a nextgeneration model of mesoscale assimilation system forecasting to assist in understanding and forecasting mesoscale rainfall systems. The WRF model is applied in various problems that include several advantages, among others [8].

The WRF model requires input, namely NCEP global analysis (FNL) data. There are subsequent programs, which are required to create a domain (boundary) of the research area in both the WPS program (WRF Pre-Processing System) and the WRF program with the Ndown.exe menu in the Namelist program editor.

To carry out the operation of the WRF model program which is incorporated into the two programs, namely WPS and WRF, the WRF output results are obtained. Then the output is processed with the convert to grads program until numerical results are obtained in the GrADS format.

The data used in this study are [11],[12]:

1) Daily rainfall data for BMKG, ARG, and AWS stations in the South Sulawesi region from 21 to 22 January 2019 and monthly rainfall data for 2009 to 2019.

2) Re-analysis of WRF model FNL data with a spatial resolution of $18 \mathrm{~km}$.

3) Himawari-8 imagery on January 21 and 22, 2019.

4) Weather Radar imagery on January 21, 2019.

The data is processed using WRF-EMS and GrADS software, then the output of the software will be analyzed and compared with climatological conditions, global conditions, and regional conditions.

\section{RESULTS AND DISCUSSIONS}

Cumulonimbus cloud ( $\mathrm{Cb}$ ) is a type of cumulus cloud with a large vertical thickness and is a mixture of ice crystals at the top and water droplets at the bottom, this characteristic causes heavy rain but after a long period of heavy rain, drizzle. can still happen. happened in a very long time. Its life span is approximately 2 hours.

When viewed from the direction and velocity of the vertical flow of the Cb cloud cycle, there are three stages of cloud Cb growth, namely [13],[14]:

1) Growth Stage (Cumulus Stage) Inside the cloud there is a strong rising current. At this stage there is no rain yet, the water droplets and ice crystals are still held back by the air currents rising above the cloud tops.

2) Maturity Stage At this stage the water droplets are no longer held back by the air rising to the top of the cloud. Then the rain falls causing the frictional force between the air currents to rise and fall.

3) Dead Stage (Disposal Stage) At this stage no air mass is rising, the falling air mass extends throughout the cloud. The condensation process stops, the descending air weakens until the growth of Cumulonimbus $(\mathrm{Cb})$ clouds stops. 
Rain intensity is the height or depth of rainwater per unit time, in other words, that the intensity of rainfall states the amount of rainfall in the short term which gives an idea of the amount of rain per hour. To get the value of rain intensity in a place, the rain gauge used must be able to record the volume of rain and the length of time the rain stops.

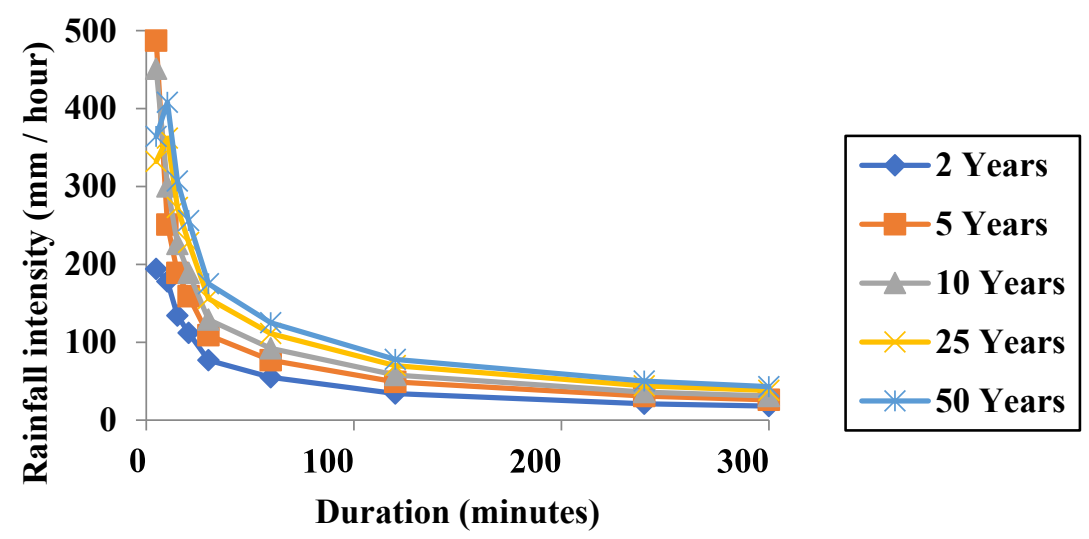

Figure 1: Rainfall Intensity of South Sulawesi for Period 2, 5, 10, 25, and 50 Years.

Rain intensity values that are shown in the graph of the relationship between the duration of rain (duration) in minutes and the intensity of rain in the return period of 2 years, 5 years, 10 years, 25 years, and 50 years are the result of calculations using the Mononobe model. the highest rain. This needs to be a concern, there are indications that within 5 years in the study area there will be high-intensity rainfall [7].

Based on the value of the atmospheric stability index (CAPE) from the model output, it can be seen that on January 21, 2019, at 00 UTC, the high CAPE value ranged from 2500-3000 J / Kg. Then the CAPE value decreased drastically at $12 \mathrm{UTC}$, namely in the range of 0-500 J / Kg. This corresponds to known rainy periods from AWS and ARG data. Where the rain started to occur on January 21, 2019, at 03.30 UTC. On January 22, 2019, at 00 UTC, the CAPE value ranged from 1500-2000 J / Kg, this value is quite high and it can be assumed that the potential for convective cloud growth is quite high (Figure 2.). So it can be concluded that the energy available for convective cloud growth in the South Sulawesi region is in the period January 21, 2019, at 00 UTC [15],[16],[17].
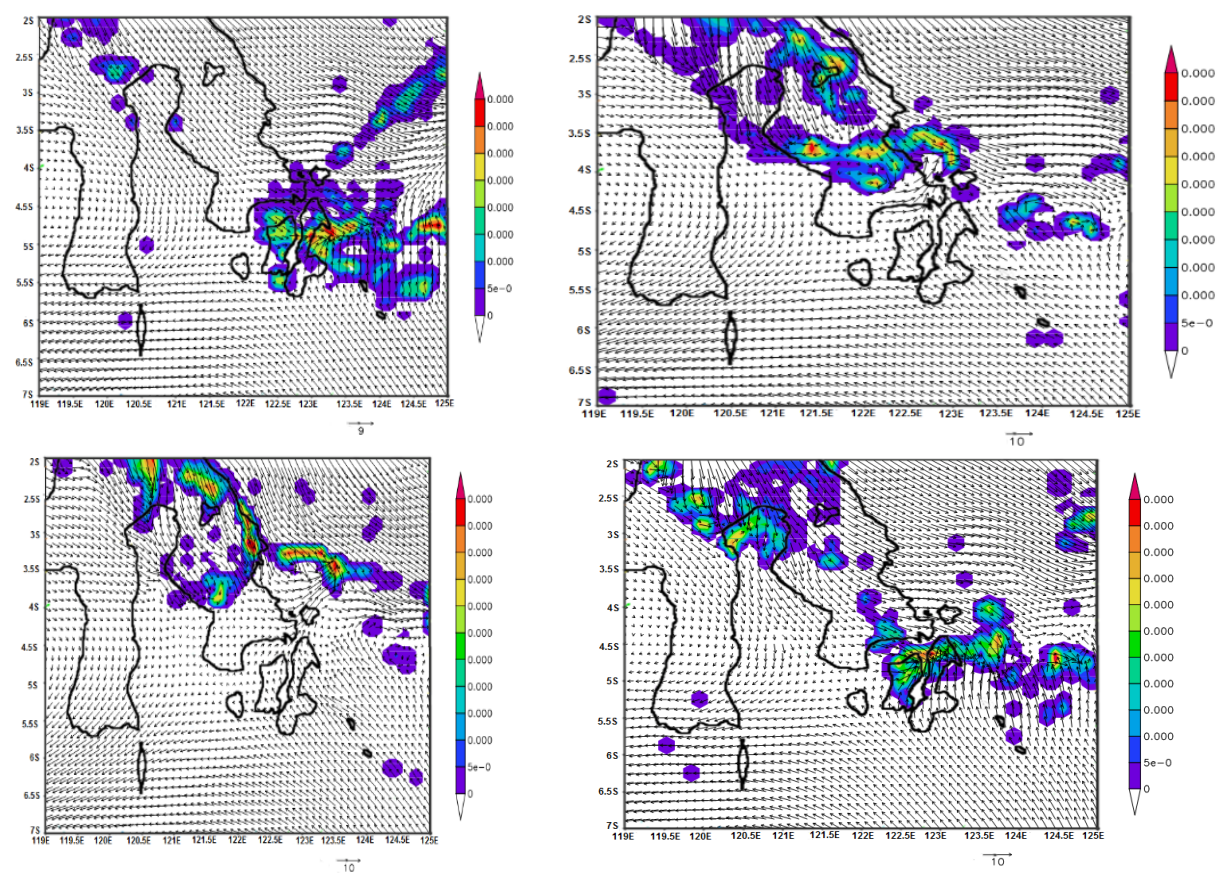

Figure 2: The CB cloud distribution model results for January 21 at 00 UTC to January 22 at 00 UTC 
Based on 3 hours of rainfall data from the BMKG Gowa Automatic Rain Gauge (ARG), rain began to occur on January 21, 2019, at 03.20 UTC and continued for the next 2 days, namely January 23, 2019, at 04 UTC. Then for 3 hours of rainfall data from BMKG Automatic Weather Station Hasanuddin, the rain began to occur on January 21, 2019 , from 00.10 UTC to 23.50 UTC with accumulated rain for 24 hours reaching $169.4 \mathrm{~mm}$. The duration with the highest rainfall intensity is $61.2 \mathrm{~mm}$ /hour which is included in the category of heavy rain intensity in the period between 18.10-18.30 UTC. Based on 3-hour rainfall data from BMKG Automatic Weather Station (AWS), rain began to occur on January 21, 2019, from 04.30 UTC to 23.30 UTC with accumulated rain for 24 hours reaching $71 \mathrm{~mm}$. The duration with the highest rainfall intensity is $72 \mathrm{~mm}$ / hour which is included in the category of heavy rain intensity in the period between 16.40-16.50 UTC [18],[19].
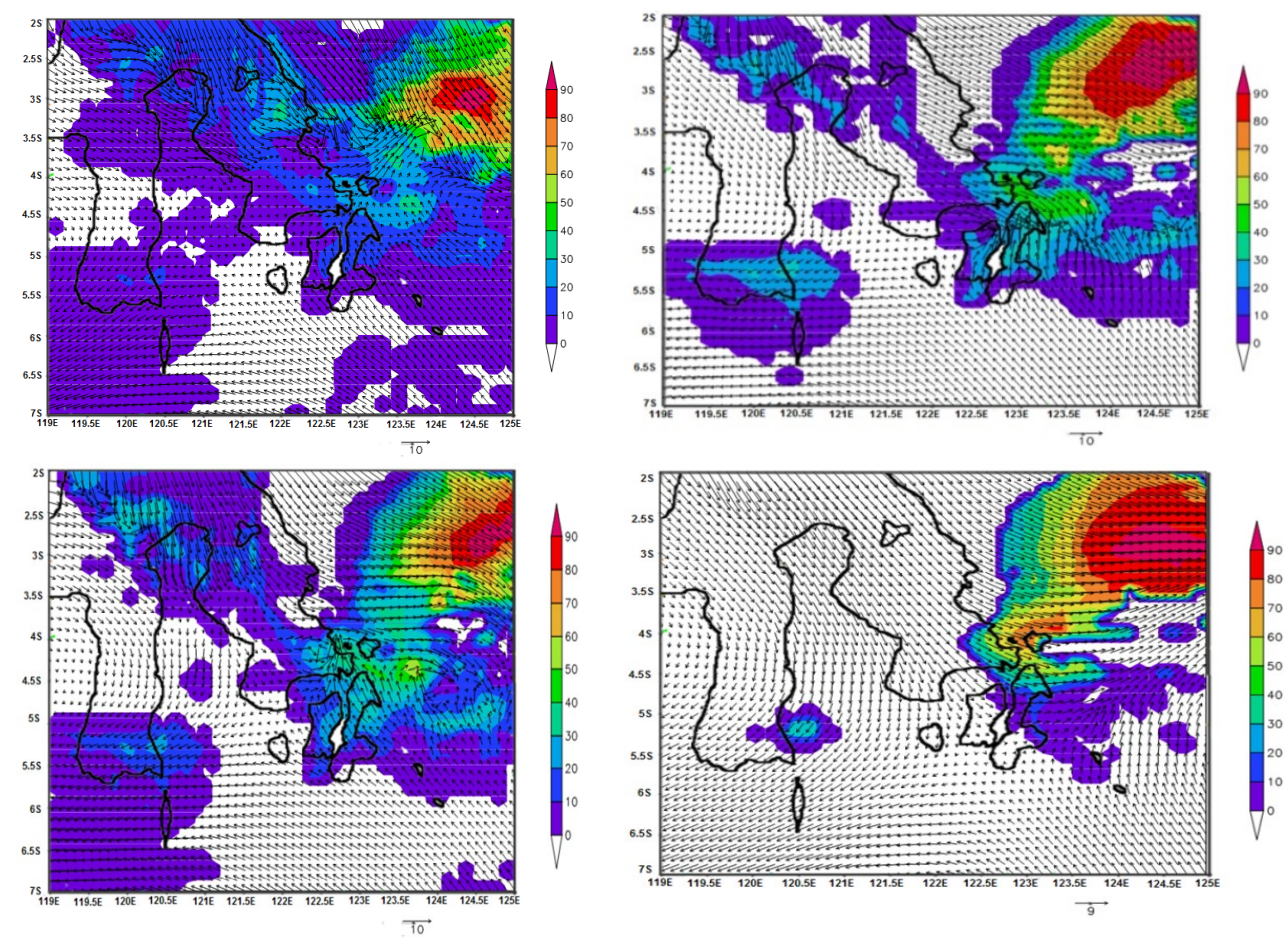

Figure 3: Results of the spatial rainfall model for January 21 at 00 UTC to January 22 at 00 UTC

Figure 3 shows the distribution of rainfall in the South Sulawesi region. Analysis on the WRF model did not show any significant rainfall, on January 21, 2019, at 00 UTC and January 222019 at 00 UTC the rainfall only occurred in the light-heavy category, which ranged from 0-30 mm. However, the rainfall is quite heavy, ranging from $60-90 \mathrm{~mm}$ above sea level in the South Sulawesi region. The rainfall value from the output of this model is generally quite good, but due to incorrect numerical calculations, it cannot represent the incidence of high-intensity rain in the study area [20],[21].

Based on the analysis of both the mononobe model and the WRF model, the initial causes of extreme rainfall were found, this is an important point as a variable in decision making for disaster management in Indonesia in the future. As is well known, the high factor of hydrometeorological disasters in the tropics requires disaster management planning as early as possible to minimize casualties [22],[23].

\section{CONCLUSIONS AND RECOMMENDATIONS}

Based on the results of the research that has been done, the following conclusions are obtained:

1) Research at WRF-EMS is carried out in 3 stages, namely the domain set stage, the preparation stage, the running stage, and the post-stage. The WRF model can represent the moisture value of the upper layer quite well during extreme rainfall in the South Sulawesi region.

2) There was rain with light to very heavy intensity from January 21, 2019, to January 22, 2019, which was caused by Cumulonimbus type clouds. Meteorological conditions in the form of an active Asian monsoon, warm sea surface temperatures, and high humidity in the lower to moderate atmosphere support 
Rahmat Gernowo, and Muhamad Irham Nurwidyanto

optimal rain cloud growth in the South Sulawesi region. Based on the modeling results, it can be seen that on January 21,2019, rain in the South Sulawesi region occurred during the day and at night. Meanwhile, on January 22, 2019, there was rain with very heavy intensity.

3) The need for the above variables to become initial input in disaster management planning in the tropics, especially in Indonesia.

\section{SOURCES OF FUNDING}

This research received no specific grant from any funding agency in the public, commercial, or not-for-profit sectors.

\section{CONFLICT OF INTEREST}

The author have declared that no competing interests exist.

\section{ACKNOWLEDGMENT}

The authors would like to express heartfelt thanks to Non-APBN OPOC Program Research Diponegoro University, 2019/2020 Budgeting for providing financial support.

\section{REFERENCES}

[1] Hidayat R, Juniarti MD, Ma'rufah U. Impact of La Niña and La Niña Modoki on Indonesia rainfall variability. IOP Conf. Ser.: Earth Environ. Sci. 2018; 149012046.

[2] Siswanto Geert JVOB, Gerald VDS, Lende RK, Bart VDH. Trends in High-Daily Precipitation Events in Jakarta and Flooding of January 2014, Special Supplement to the Bulletin of the American Meteorological Society. 2015; 96(12).

[3] Hou T, Lei H, Yang J, Hu Z, Feng Q. Investigation of riming within mixed-phase stratiform clouds using Weather Research and Forecasting (WRF) model. Atmospherics Research Journal. 2016; 178-179: 291-303.

[4] Abidin HZ, Andreas H, Gumilar I, Wibowo IR. On the correlation between urban development, land subsidence, and flooding phenomena in Jakarta. Proc. IAHS. 2015; 370: 15-20.

[5] Mori S, Jun-Ichi H, YudiIman T, Yamanaka MD, Okamoto N, Murata F, Sakurai N, Hashiguchi H, Sribimawati T. Diurnal Land-Sea Rainfall Peak Migration over Sumatra Island, Indonesia Maritime Continent, Observed by TRMM Satellite and Intensive Rawinsonde soundings, American Meteorological Society. 2004; 20212039.

[6] Sakurai N, Murata F, Yamanaka MD, Mori S, Hamada JI, Hasiguchi H, Tauhid YI, Sribimawati T, Suhardi B. Diurnal Cycle of Cloud System Migration over Sumatera Island. Journal of the Meteorological. 2005;83(5).

[7] Wooyoung Na and Chulsang Yoo. Evaluation of Rainfall Temporal Distribution Models with Annual Maximum Rainfall Events in Seoul, Korea, Water 2018, 10, 1468; doi:10.3390/w10101468.

[8] Skamarock WC, Klemp JB, Dudhia J, Gill DO, Barker DM, Wang W, and Powers JG. A Description of the Advanced Research WRF Version 2, Mesoscale and Microscale Meteorology Division, National Center for Atmospheric Research Colorado USA. 2005.

[9] Chaudhry FH, Filho AGA, Calheiros RV. Statistics on Tropical Convective Storms Observed by Radar, Atmospheric Research. 1996; 42: 217-227.

[10] Roxana C, Wajsowicz. Forecasting extreme events in the tropical Indian ocean sector climate. Journal dynamics of atmospheres, and ocean. 2005; 1-15.

[11] Meteorology Climatology and Geophysics Council (BMKG), Climate Analysis. 2020.

[12] National Disaster Management Authority (BNPB), Indonesian Disaster Information Data 2000-2020, https://bnpb.go.id/infografis/update-bencana-indonesia-tahun-2020

[13] Gernowo R, Adi K, Yulianto T. Convective Cloud model for Analyzing of Heavy rainfall of Weather Extreme at Semarang Indonesia. Advanced Science Letter. 2017; 23(7): 6593-6597. 
[14] Thompson G, Tewari M, Ikeda K, Tessendorf S, Weeks C, Orkin J, Kong F. Explicitly-coupled cloud physics and radiation parameterizations and subsequent evaluation in WRF high-resolution convective forecasts. Atmospherics Research Journal. 2016;168: 92-104

[15] Gernowo R, Adi K, Yulianto T, Seniyatis S, Yatunnisa AA. Hazard Mitigation with Cloud Model-based rainfall and Convective data. Journal of Physics: Conference Series. 2018; 1025(1): 012023.

[16] Castellano NE, Avila EE, Sounders CPR.Theoretical Model of the Bergeron-Fiendeisen Mechanism of Ice Crystal Growth in Clouds, Atmospheric Environment. 2004; 38: 6751-6761.

[17] Hong S-Y, H-L Pan. Nonlocal boundary layer vertical diffusion in a medium-range forecast model, Mon. Wean. Rev. 1996; 124: 2322-2339.

[18] Masouleh ZP, Walker DJ, Crowther JM. A Long-Term Study of Sea-Breeze Characteristics: A Case Study of the Coastal City of Adelaide. J. Appl. Meteor. Climatol. 2019; 58(2): 385-400.

[19] Cooley D, D Nychka, PNaveau. Bayesian spatial modeling of extreme precipitation return levels. J. Amer. Stat. Assoc. 2007; 102: 824-840.

[20] Diaz HF, MPHoerling, JKEischeid. ENSO variability, teleconnections, and climate change. Int., J. Climatol. 2001; 21: $1845-1862$.

[21] Roy I, Tedeschi RG, Collins M. ENSO teleconnections to the Indian summer monsoon under climate changing. International Journal of Climatology. 2019; 39(6): 3031-3042.

[22] Prasetyo Y, Yuwono BD, Ramadhanis Z. Spatial Analysis of Land Subsidence and Flood Pattern BasedonDInSAR Method in Sentinel Sar Imagery and Weighting Method in Geo-Hazard Parameters Combination in NorthJakarta Region. IOP Conf. Series: Earth and Environmental Science. 2018; 123012009.

[23] Hashiguci H, S Fukao, T Tsuda, MD Yamanaka, SWB Harijono, H Wiryosumarto. An Overview of The Planetary Boundary Layer Observation Over Equatorial Indonesia with an L-Band Clear Air Doppler Radar, Beitr. Phy. Atmos. 1996;69: 13-25. 